\title{
PEINGKATKAN PEMAHAMAN PADA MATA PELAJARAN IPS PADA SISWA KELAS V DENGAN MENGGUNAKAN QUIS GAME DI SDN SENDANGREJO I KECAMATAN LAMONGAN
}

\author{
Puji Suprihatin \\ pujisuprihatn@gmail.com \\ SDN Sendangrejo I
}

\begin{abstract}
Abstrak
Penelitian ini dilatarbelakangi oleh karena diperlukannya suatu metode pembelajaran yang dapat membuat pembelajaran terasa lebih aktif, kreatif, efektif, dan menyenangkan, serta mengurangi kejenuhan dan kebosanan dalam belajar. Salah satu metode yang diperkenalkan dalam penelitian ini adalah metode permainan kuis cerdas cermat. Metode permainan kuis cerdas cermat merupakan sebuah metode ujian lisan yang singkat berupa perlombaan adu cepat menjawab pertanyaan.

Permasalahan dalam penelitian ini adalah belum diketahui adanya pengaruh penggunaan metode permainan kuis cerdas cermat terhadap kemampuan siswa di kelas V SD Negeri Sendangrejo I Kecamatan Lamongan Kabupaten Lamongan. Untuk menjawab permasalahan tersebut maka peneliti mengajukan hipotesis yang berbunyi : jika pembelajaran dilakukan dengan menggunakan metode permainan kuis, maka pemahaman pada mata pelajaran IPS pada siswa akan meningkat.

Populasi dari penelitian ini adalah seluruh siswa kelas V SD Negeri Sendangrejo I Kecamatan Lamongan Kabupaten Lamongan Tahun Pelajaran 2017/2018 yang berjumlah 20 orang, sedangkan sampel dari penelitian ini adalah seluruh jumlah populasi yaitu 20 siswa sehingga penelitian ini disebut juga dengan penelitian populasi.

Penelitian ini menggunakan metode penelitian tindakan kelas yang terdiri dari beberapa siklus dengan setiap siklus terdapat perencanaan, tindakan, pengamatan, dan refleksi. Instrumen yang digunakan berupa angket, Rencana Pembelajaran (RP), Lembar Kegiatan Siswa (LKS), dan penilaian kelas. Analisis data digunakan untuk memperoleh data tentang ketuntasan belajar perorangan dan klasikal didapatkan dari penilaian kinerja. Ketuntasan belajar perorangan didapat jika nilai/skor $\geq 60$ dan ketuntasan belajar klasikal diperoleh jika persentase siswa yang tuntas belajar perorangan $\geq 85 \%$.

Penelitian ini dilakukan melalui dua siklus yaitu siklus I dan siklus II. Pada siklus I terdapat 8 siswa yang mengalami ketuntasan belajar perorangan dari 20 jumlah siswa (25\%) ini menunjukkan pada siklus ini belum mengalami ketuntasan klasikal. Pada siklus II terdapat 20 siswa yang mengalami ketuntasan belajar perorangan dari 20 jumlah siswa (100\%) ini menunjukkan pada siklus ini sudah mengalami ketuntasan klasikal, dan berdasarkan hasil penelitian dapat disimpulkan bahwa penggunaan metode kuis dapat meningkatkan prestasi belajar siswa.
\end{abstract}

\section{Kata Kunci : Pelajaran IPS, Question Tes}

\section{PENDAHULUAN}

Bangsa dan masyarakat Indonesia akan memasuki era pasar bebas, dimana setiap orang dapat melakukan berbagai aktivitas di Indonesia dengan kompetisi obyektif, tanpa melihat asal usul kewarganegaraannya. Kondisi tersebut merupakan tonggak yang amat kritis, karena kemajuan suatu negara bergantung kepada kualitas sumber daya manusia dan kemajuan teknologi yang dimilikinya untuk dapat bersaing secara global, kompetitif, dan kooperatif. Kunci utama pembahagiaan anak didik dalam konteks pembelajaran adalah pemberian hak dan kewajiban yang seimbang kepada mereka untuk merealisasikan dirinya secara maksimal dalam belajar dan pembelajaran berbasis lingkungan. Peran guru dan pengelola sekolah sangat menentukan dalam penciptaan kondisi dan situasi belajar-mengajar yang terjadi di sekolah. Dalam pembelajaran Ilmu Pengetahuan Sosial pada kelas-kelas yang lebih tinggi terutama dalam penelitian ini yaitu kelas $\mathrm{V}$ maka pembelajaran yang digunakan dapat menggunakan media yang abstrak. Siswa 
kelas $\mathrm{V}$ merupakan siswa kelas atas yang sudah berkembang daya imajinasi dan kreatifitasnya, sehingga pembelajaran dengan menggunakan media yang abstrak sudah dapat diterapkan. Namun demikian pembelajaran masih harus mendekatkan pada pembelajaran aktif, kreatif, efektif, dan menyenangkan. Salah satu pendekatan belajar yang dapat diterapkan adalah metode permainan/lomba kuis cerdas cermat berkelompok. Permainan ini sudah sering digunakan oleh guru untuk melihat kemampuan anak setelah dilakukan pembelajaran sebelum dilakukan evaluasi (penilaian). Permainan ini sangat baik dilakukan karena dapat melihat sebagaimana besar kemampuan siswa menyerap pemahaman pelajaran setelah dilakukan proses pembelajaran, sehingga jika dalam permainan ini banyak yang masih tidak dapat menjawab pertanyaan atau hanya siswa tertentu saja yang menjawabnya maka guru dapat melakukan pembelajaran ulang. Karena pembelajaran ini merupakan suatu metode permainan atau lomba maka pembelajaran dengan cara ini sangat menyenangkan karena yang menang akan mendapat hadiah atau penghargaan.

Bertitik tolak dari latar belakang di atas maka penulis merumuskan permasalahannya sebagai berikut: (1) Bagaimana penggunaan permainan cerdas cermat / kuis untuk meningkatkan pemahaman mata pelajaran IPS pada siswa kelas V SD Negeri Sendangrejo I Kecamatan Lamongan Kabupaten Lamongan Tahun Pelajaran 2017/2018 ? (2) Bagaimana pelaksanaan pembelajaran dengan menggunakan permainan cerdas cermat / kuis untuk meningkatkan pada siswa kelas V SD Negeri Sendangrejo I Kecamatan Lamongan Kabupaten Lamongan Tahun Pelajaran 2017/2018?

Sesuai dengan permasalahan di atas, penelitian ini bertujuan untuk: (1) Mengetahui pengaruh permainan cerdas cermat / kuis terhadap peningkatan pemahaman pelajaran IPS pada siswa kelas V SD Negeri Sendangrejo I Kecamatan Lamongan Kabupaten Lamongan Tahun Pelajaran 2017/2018. (2) Mengetahui pelaksanaan pembelajaran dengan menggunakan permainan cerdas cermat / kuis terhadap peningkatan pemahaman pelajaran IPS pada siswa kelas V SD Negeri Sendangrejo I Kecamatan Lamongan Kabupaten Lamongan Tahun Pelajaran 2017/2018

Adapun maksud penulis mengadakan penelitian ini diharapkan berguna untuk: (1) Menambah pengetahuan dan wawasan penulis tentang peranan guru dalam meningkatkan kemampuan siswa belajar Ilmu Pengetahuan Sosial. (2) Sumbangan pemikiran bagi guru dalam mengajar dan meningkatkan prestasi belajar siswa.

Metode adalah cara yang digunakan untuk menyampaikan materi pelajaran dalam upaya untuk mencapai tujuan pembelajaran. Dewasa ini keaktifan siswa mendapat tekanan utama dalam pembelajaran dibanding dengan keaktifan guru yang bertindak sebagai fasilitator dan pembimbing bagi siswa. Metode atau strategi pembelajaran menempati fungsi yang sangat penting, karena memuat tugas-tugas yang perlu dikerjakan siswa dan guru, karena itu penyusunannya hendaknya berdasarkan analisis tugas yang mengacu pada tujuan pembelajaran. Bila topik yang akan dibahas itu luas, berbagai ragam metode dapat digunakan. Karena penggunaan berbagai metode ini dapat saling menutupi kekurangan pada metode yang lain. Biasanya metode mengandung unsure-unsur: (a) Uraian tentang apa yang akan dipelajari. (b) Diskusi dan pertukaran pikiran. (c) Kegiatan-kegiatan yang menggunakan berbagai alat instruksional, laboratorium, dan lain-lain. (d) Kegiatankegiatan dalam lingkungan sekitar sekolah seperti kunjungan, kerja lapangan, eksplorasi, dan penelitian. (e) Kegiatankegiatan dengan menggunakan berbagai sumber belajar seperti buku perpustakaan, alat audio visual, dan lain-lain. (f) Kegiatan kreatif seperti drama, seni rupa, 
musik, pekerjaan tangan dan sebagainya (Sagala, 2003:169)

Dalam menggunakan model mengajar sudah barang tentu guru yang tidak mengenal metode mengajar jangan diharap bisa melaksanakan proses belajar mengajar sebaik-baiknya. Hal yang penting dalam metode adalah bahwa setiap metode pembelajaran yang digunakan bertalian dengan tujuan belajar yang ingin dicapai. Tujuan untuk mendidik anak agar sanggup memecahkan masalah-masalah dalam belajarnya, memerlukan metode yang lain, bila tujuannya mengumpulkan informasi. Oleh karena itu untuk mendorong keberhasilan guru dalam proses belajarmengajar, guru seharusnya mengerti akan fungsi, langkah-langkah pelaksanaan metode mengajar. (Sagala, 2003:201). Metode permainan kuis adalah sebuah metode ujian lisan yang singkat berupa perlombaan adu cepat menjawab pertanyaan. Dalam permainan ini siapa yang dapat menjawab dengan cepat dan tepat yang paling banyak maka dialah yang menjadi pemenangnya dan berhak menerima hadiah atau penghargaan. Permainan kuis cerdas cermat dilakukan pada akhir pembelajaran sebelum dilakukan evaluasi (penilaian) yang sebenarnya. Metode permainan kuis cerdas cermat merupakan modifikasi metode pembelajaran yang diciptakan oleh guru untuk mewujudkan pembelajaran yang bervariasi, sehingga kejenuhan dan kebosanan dalam belajar akan berkurang.

Banyak pihak termasuk dari kalangan pendidik yang menggunakan pengertian rancu tentang ilmu pengetahuan sosial dengan ilmu-ilmu sosial. Seperti yang diungkapkan Welton dan Mallan ( 1981 ), Duffie dan Sagl ( 1966 ) dalam Maksum ( 1997:12 ) menyatakan bahwa IPS bukan hanya kurang popular tetapi juga sering "disalahtafsirkan" dan "dikacaukan" dengan ilmu-ilmu sosial. IPS merupakan perpaduan antara konsep-konsep ilmu sosial dengan konsep-konsep Pendidikan yang dikaji secara sistemaits, psikologis dan fungsional sesuai dengan tingkat perkembangan anak didik (Somantri, 1996:2). Perpaduan antara ilmu-ilmu sosial dan Pendidikan dalam sajian IPS disebut dengan istilah sinthetyc disiplin. Berkenaan dengan batasan pengertian IPS, Sumaatmadja (1980:11) mengemukakan bahwa :

"Secara mendasar, pengajaran IPS berkenaan dengan kehidupan manusia yang melibatkan segala tingkah laku dan kebutuhannya. IPS berkenaan dengan cara manusia menggunakan usaha memenuhi kebutuhan materinya, memenuhi kebutuhan budayanya, kebutuhan jiwanya, kemanfaatan sumberdaya yang ada di permukaan bmi, mengatur kesejahteraan dan pemerintahannya, dan lain sebagainya yang mengatur serta mempertahankan kehidupan masyarakat manusia. Pokoknya mempelajari-menelaah-mengkaji

system kehidupan manusia dipermukaan bumi ini, itulah hakikat yang di pelajari pada pelajaran IPS".

Berdasarkan pendapat di atas, tampak bahwa IPS bukan ilmu sosial, tetapi pengertian IPS hampir sama bahkan sama pengertiannya dengan studi sosial atau social studies, sehingga Sumaatmadja (1980:10) mengemukakan bahwa pengertian studi sosial dengan IPS tidak ada bedanya. Kalau kita katakan bahwa IPS diajarkan dari sekolah dasar sampai tingkat lanjutan, artinya sama dengan studi sosial diajarkan mulai SD sampai perguruan tinggi. Oleh karena itu, jika pada kutipan bahasa inggris kita dapati kalau social studies, itu berarti sama dengan IPS.

Metode atau strategi pembelajaran menempati fungsi yang sangat penting, karena memuat tugas-tugas yang perlu dikerjakan siswa dan guru, karena itu penyusunannya hendaknya berdasarkan analisis tugas yang mengacu pada tujuan 
pembelajaran. Hubungan metode pembelajaran dengan prestasi belajar adalah merupakan rangkaian antara metode dengan prestasi belajar. Dari kedua hal tersebut saling pengaruh mempengaruhi dan saling saling isi mengisi sehingga tidak dapat terpisahkan diantara keduanya. Hal ini sesuai dengan pendapat WJS Purwodarminto yang menjelaskan bahwa "hubungan metode pembelajaran dengan prestasi belajar berarti mempunyai pertalian yang sangat kuat".

Penggunaan metode mengajar sangat berpengaruh terhadap proses pembelajaran, metode mengajar merupakan masalah penggunaan cara untuk memotivasi belajar, sehingga akan terjadi dengan mudah dan menyenangkan. Semakin baik media mengajar semakin efektif pada pencapaian tujuan pengajaran. Pemilihan metode mengajar tertentu akan meningkatkan motivasi, dan motivasi ini merupakan kunci belajar efektif. Sistem penyampaian yang dipilih oleh guru akan menentukan mutu interaksi yang terjadi, dan mutu interaksi ini akan menentukan prestasi belajar siswa.

Dalam penelitian ini penulis mengajukan hipotesis:

"Jika pembelajaran dilakukan dengan menggunakan permainan cerdas cermat / kuis , maka pemahaman mata pelajaran IPS pada siswa kelas V SD Negeri Sendangrejo I Kecamatan Lamongan Kabupaten Lamongan Tahun Pelajaran 2017/2018 akan meningkat".

\section{METODE}

Pelaksanaan penelitian ini untuk: (a) Mengetahui bagaimana pelaksanaan pembelajaran IPS kelas V di SD Negeri Sendangrejo I Kecamatan Lamongan Kabupaten Lamongan Tahun Pelajaran 2017/2018 dengan menggunakan permainan kuis / cerdas cermat. (b) Mengetahui hambatan-hambatan yang dihadapi dalam melakukan pembelajaran IPS melalui permainan kuis cerdas cermat. (c) Mengetahui kelemaham dan kelebihan permainan kuis cerdas cermat pada pembelajaran IPS. (d) Dilakukan perbaikan dan peningkatan praktek pembelajaran secara berkesinambungan. (e) Mengetahui hasil pembelajaran IPS melalui permainan kuis cerdas cermat.

PTK adalah untuk memperbaiki/meningkatkan praktek secara berkesinambungan, sedangkan tujuan pernyataannya adalah menumbuhkan budaya meneliti di kalangan guru. (Riduwan, 2004:3)

Sesuai dengan jenis penelitian tindakan dari Kemmis dan Taggart yaitu berbentuk spiral dari siklus yang satu ke siklus yang berikutnya. Setiap siklus meliputi perencanaan (planning), tindakan (action), pengamatan (observation), dan refleksi (reflection). Langkah pada siklus berikutnya adalah perencanaan yang sudah direvisi, tindakan, pengamatan dan refleksi. Sebelum masuk pada siklus I dilakukan tindakan pendahuluan yang berupa identifikasi permasalahan.

Penelitian ini merupakan penelitian tindakan kelas yang mana populasi juga merupakan sampel. Sehingga yang dimaksud dengan populasi dan sampel dalam penelitian ini adalah semua siswa kelas V SD Negeri Sendangrejo I Kecamatan Lamongan Kabupaten Lamongan Tahun Pelajaran 2017/2018 yang berjumlah 20 siswa. Instrumen yang digunakan dalam penelitian ini terdiri dari:

(1) Angket Siswa, (2) Rencana Pembelajaran. (3) Lembar Kegiatan Siswa. (4) Penilaian Kelas.

Dalam peneiltian tindakan ini menggunakan bentuk guru sebagai peneliti, penanggung jawab penuh penelitian ini adalah guru. Tujuan utama dari penelitian tindakan ini adalah untuk meningkatkan hasil pembelajaran di kelas dimana guru secara penuh terlibat dalam penelitian mulai dari perencanaan, tindakan, pengamatan, dan refleksi. Dalam 
penelitian ini peneliti tidak bekerja sama dengan siapapun, kehadiran peneliti sebagai guru di kelas sebagai pengajar tetap dan dilakukan seperti biasa, sehingga siswa tidak tahu kalau diteliti. Dengan cara ini diharapkan didapatkan data yang seobyektif mungkin demi kevalidan data yang diperlukan. Hasil penilaian kelas dianalisis untuk mendapatkan umpan balik tentang berbagai komponen dalam proses pembelajaran dan untuk menentukan kegiatan tindak lanjut yang tepat. Tindak lanjut diberikan sebagai suatu tindakan terhadap umpan balik yang diterima dari pelaksanaan penilaian kelas. Analisis penilaian kelas atau persentase keberhasilan siswa setelah proses belajar mengajar setiap putarannya dalam penelitian ini dilakukan dengan cara memberikan evaluasi berupa tes tulis pada setiap akhir putaran. Peneliti melakukan penjumlahan nilai yang diperoleh siswa, yang selanjutnya dibagi dengan jumlah siswa yang ada di kelas tersebut sehingga diperoleh rata-rata penilaian dapat dirumuskan :

$$
\bar{X}=\frac{\sum \mathrm{X}}{\sum \mathrm{N}}
$$

Dengan $: \bar{X}=$ Nilai rata-rata $\sum X=$ Jumlah semua nilai siswa $\sum \mathrm{N}=$ Jumlah siswa

Ada dua kategori ketuntasan belajar yaitu secara perorangan dan secara klasikal. Seorang siswa telah tuntas belajar bila telah mencapai skor $60 \%$ atau nilai 60, dan kelas disebut tuntas belajar bila di kelas tersebut terdapat $85 \%$ yang telah mencapai daya serap lebih dari atau sama dengan $60 \%$. Untuk menghitung persentase ketuntasan belajar digunakan rumus sebagai berikut :

$$
\mathrm{P}=\frac{\sum \text { Siswa yang tuntas belajar }}{\sum \text { Siswa }} \times 100 \%
$$

\section{SIKLUS I}

Pada tahap ini peneliti mempersiapkan perangkat pembelajaran yang terdiri dari RP 1, LKS 1 dan alat-alat pengajaran yang mendukung.

Pelaksanaan kegiatan belajar mengajar untuk siklus I yang dilaksanakan dua kali pelaksanaan yaitu pada hari Kamis tanggal 7 dan 21 September 2017 di kelas V dengan jumlah siswa 20 siswa. Dalam hal ini peneliti bertindak sebagai guru. Adapun proses belajar mengajar dan langkah-langkah pembelajaran mengacu pada RP yang telah disiapkan. Pengamatan (observasi) dilaksanakan bersamaan dengan pelaksanaan belajar mengajar. Pada akhir proses belajar mengajar siswa diberi penilaian berupa tes tulis dengan tujuan untuk mengetahui tingkat keberhasilan siswa dalam proses belajar mengajar yang telah dilakukan.

Tabel IV.2.

\begin{tabular}{|c|c|c|}
\hline No. & Uraian & Hasil Siklus I \\
\hline 1. & Nilai rata-rata tes & 53,25 \\
\hline 2. & Jumlah siswa yang tuntas belajar & 5 \\
\hline 3. & Persentase ketuntasan belajar & $25 \%$ \\
\hline
\end{tabular}

Rekapitulasi Nilai Tes Siklus I

Dari tabel di atas dapat dijelaskan bahwa dengan menerapkan metode permainan kuis cerdas cermat diperoleh nilai rata-rata belajar siswa 53,25 dan ketuntasan belajar mencapai $25 \%$ atau ada 5 siswa dari 20 siswa sudah tuntas belajar.
Hasil tersebut menunjukkan bahwa pada siklus pertama secara klasikal siswa belum tuntas belajar, karena siswa yang memperoleh nilai $\geq 60$ hanya sebesar $25 \%$ lebih kecil dari persentase ketuntasan yang dikehendaki yaitu sebesar $85 \%$. Hal ini 
disebabkan siswa masih kesulitan menghafal materi yang abstrak seperti materi mengenal benua sehingga diperlukan penambahan latihan-latihan soal untuk memotivasi siswa mau belajar.

Pada tahap ini akan dikaji apa yang telah terlaksana dengan baik maupun yang masih kurang baik dalam proses belajar mengajar dengan penggunaan metode permainan kuis cerdas cermat. Dari datadata yang telah diperoleh dapat diuraikan sebagai berikut : (1) Selama proses belajar mengajar guru telah melaksanakan semua pembelajaran dengan baik sesuai dengan RP yang telah dibuat. Meskipun ada beberapa aspek yang belum sempurna, tetapi persentase pelaksanaannya untuk masing-masing aspek cukup besar. (2) Berdasarkan data hasil pengamatan dan penilaian diketahui bahwa siswa dalam mempelajari materi kerajaan dan peninggalan Hindu, Budha dan Islam masih mengalami hambatan, diantaranya siswa masih kesulitan menghafal materi yang abstrak sehingga diperlukan penambahan latihan-latihan soal untuk memotivasi siswa mau belajar.

\section{SIKLUS II}

Pada tahap ini peneliti mempersiapkan perangkat pembelajaran yang terdiri dari RP 2, LKS 2 dan alat-alat pengajaran yang mendukung. Karena pada siklus pertama masih belum tuntas terutama terdapat kekurangan pada siswa masih kesulitan menghafal materi yang abstrak seperti materi mengenal benua, maka guru menambah keterlibatan siswa dengan cara siswa lebih aktif melakukan latihan baik di rumah (tugas rumah) maupun di kelas melalui bantuan lingkungan sekitar. Pelaksanaan kegiatan belajar mengajar untuk siklus II juga dilaksanakan dua kali pelaksanaan yaitu pada hari Kamis tanggal 5 dan 19 Oktober 2017 di kelas V dengan jumlah siswa 20 siswa. Dalam hal ini peneliti bertindak sebagai guru. Adapun proses belajar mengajar dan langkah-langkah pembelajaran mengacu pada RP yang telah disiapkan. Pengamatan (observasi) dilaksanakan bersamaan dengan pelaksanaan belajar mengajar. Pada akhir proses belajar mengajar siswa diberi penilaian tes tulis dengan tujuan untuk mengetahui tingkat keberhasilan siswa dalam proses belajar mengajar yang telah dilakukan

Tabel IV.4.

Rekapitulasi Nilai Tes Siklus II

\begin{tabular}{clc}
\hline No. & \multicolumn{1}{c}{ Uraian } & Hasil Siklus II \\
1. & Nilai rata-rata tes & 82,25 \\
2. & Jumlah siswa yang tuntas belajar & 20 \\
3. & Persentase ketuntasan belajar & $100 \%$ \\
\hline
\end{tabular}

Dari tabel IV.3. dan IV.4. di atas dapat dijelaskan bahwa dengan menerapkan metode pembelajaran melalui permainan kuis cerdas cermat diperoleh nilai rata-rata belajar siswa 82,25 dan ketuntasan belajar mencapai $100 \%$ atau ada 20 siswa dari 20 siswa sudah tuntas belajar. Hasil tersebut menunjukkan bahwa pada siklus kedua ini secara klasikal siswa sudah tuntas belajar, karena siswa yang memperoleh nilai $\geq 60$ sebesar $100 \%$ lebih besar dari persentase ketuntasan yang dikehendaki yaitu sebesar $85 \%$.
Adanya peningkatan hasil belajar pada siklus II ini hingga mengalami ketuntasan baik ketuntasan secara perorangan maupun secara klasikal dikarenakan adanya peningkatan kemampuan guru dalam menerapkan belajar aktif sehingga siswa menjadi terbiasa dengan pembelajaran seperti ini. Dengan penggunaan metode permainan kuis cerdas cermat siswa lebih mudah memahami materi yang telah disampaikan oleh guru dan siswa dapat belajar lebih karena dibantu latihan-latihan soal yang 
terdapat pada metode permainan cerdas cermat.

Pada tahap ini akan dikaji apa yang telah terlaksana dengan baik maupun yang masih kurang baik dalam proses belajar mengajar dengan menggunakan metode permainan kuis cerdas cermat. Dari datadata yang telah diperoleh dapat diuraikan sebagai berikut: (1) Selama proses belajar mengajar guru telah melaksanakan semua pembelajaran dengan baik sesuai dengan RP yang telah dibuat. (2) Berdasarkan pengamatan yang dilakukan oleh guru, siswa semakin lebih aktif selama proses belajar berlangsung. (3) Kekurangan pada siklus sebelumnya sudah mengalami perbaikan dan peningkatan sehingga hasil yang diperoleh juga menjadi meningkat atau lebih baik.(4) Untuk siswa yang masih belum mengalami ketuntasan perseorangan guru memberikan tugas baik tugas rumah maupun tugas latihan di sekolah.

Melalui hasil penelitian tersebut di atas maka dapat diketahui penggunaan metode permainan kuis cerdas cermat memiliki dampak positif dalam meningkatkan kemampuan siswa dalam pembelajaran IPS. Hal ini dapat dilihat dari semakin mantapnya pemahaman siswa terhadap materi yang disampaikan guru (ketuntasan belajar meningkat dari siklus I dan II) yaitu masing-masing $25 \%$ menjadi $100 \%$, sehingga pada siklus II ini ketuntasan belajar siswa secara klasikal telah tercapai. Dengan melihat hasil persentase peningkatan ketuntasan belajar klasikal tersebut maka hipotesis yang peneliti ajukan dapat terbukti yaitu :

"Jika pembelajaran dilakukan dengan menggunakan metode permainan kuis cerdas cermat, maka pemahaman materi kerajaan dan peninggalan Hindu, Budha dan Islam pada siswa kelas V SD Negeri Sendangrejo I Kecamatan Lamongan Kabupaten Lamongan Tahun Pelajaran 2017/2018 akan meningkat"
Berdasarkan analisis data, diperoleh aktivitas siswa dalam proses pembelajaran dalam setiap siklus mengalami peningkatan. Hal ini dibuktikan dengan semakin mantapnya pemahaman siswa terhadap materi yang disampaikan guru (ketuntasan belajar meningkat dari siklus I dan II) yaitu masing-masing $25 \%$ menjadi $100 \%$ (mengalami kenaikan sebanyak 75 $\%$ ). Hal ini menunjukkan bahwa penggunaan metode permainan kuis cerdas cermat memiliki pengaruh yang besar terhadap peningkatan pemahaman materi kerajaan dan peninggalan Hindu, Budha dan Islam pada siswa kelas V SD Negeri Sendangrejo I Kecamatan Lamongan Kabupaten Lamongan Tahun Pelajaran 2017/2018. Dalam penelitian ini tidak ada siswa yang tidak mengalami peningkatan skor/nilai dari siklus I ke siklus II. Namun begitu nilai rata-rata siswa pada siklus I ke siklus II hanya mengalami peningkatan 29 saja dari sebelumnya 53,25 pada siklus I menjadi 82,25 pada siklus II.

\section{KESIMPULAN}

Dari hasil kegiatan pembelajaran yang telah dilakukan selama dua siklus dan berdasarkan seluruh pembahasan serta analisis yang telah dilakukan dapat disimpulkan sebagai berikut: (1) Pembelajaran dengan menggunakan metode permainan kuis cerdas cermat dapat meningkatkan pemahaman mata pelajaran IPS pada siswa kelas V SD Negeri Sendangrejo I Kecamatan Lamongan Kabupaten Lamongan Tahun Pelajaran 2017/2018 yang ditandai dengan peningkatan ketuntasan belajar klasikal siswa dalam siklus I $(28,57 \%)$ dan siklus II $(100 \%)$ dan peningkatan nilai rata-rata siswa yaitu 56,42 pada siklus I menjadi 80,71 pada siklus II. (2) Pelaksanaan pembelajaran dengan menggunakan metode permainan kuis cerdas cermat telah berjalan dengan baik. Guru dapat memberikan motivasi kepada siswa, sekaligus melakukan perbaikan pada siklus 
p-ISSN: 2503-1228; e-ISSN: 2621-4172

selanjutnya untuk mengurangi kelemahan maupun kesalahan dan menjauhkan hambatan yang dialami guru selama proses pembelajaran.

\section{DAFTAR PUSTAKA}

Arikunto, Suharsimi. 2002. Prosedur Penelitian Suatu Pendekatan Praktek. Jakarta: Rineksa Cipta.

Departemen Pendidikan Nasional, Direktorat Jenderal Pendidikan Dasar 2002. Manajemen Peningkatan Mutu Berbasis Sekolah, Buku 5, Pembelajaran dan Pengajaran Kontekstual. Jakarta: Depdiknas.
Guntur, Henry Traigan. 1980. Menyimak Sebagai Suatu Ketrampilan Berbahasa. Bandung : Angkasa.

Rahmanto, B. 1988. Pembaca dan menilai Sastra. Yogyakarta : Karnisius.

Departemen Pendidikan Nasional, Direktorat Jenderal Pendidikan Dasar, 2002, Buku Bahasa Indonesia BSE Kelas V

Buku Bahasa Indonesia Penerbit Erlangga Kelas V Jakarta

Riduwan. 2004. Belajar Mudah Penelitian untuk Guru-Karyawan dan Peneliti Pemula. Bandung: Alfabeta.

Tim Penelitian Pendidikan IKIP Surabaya. 1993 Pengantar Penelitian Pendidikan, Surabaya, University Press IKIP Surabaya. 